\title{
ADVOKAT SYARIAH DALAM MEDIASI PERKARA PERCERAIAN MENURUT MAQASHID AL SYARIAH
}

\author{
Erie Hariyanto dan $\mathcal{N i}$ 'matunnuriyah \\ Jurusan Syariah STAIN Pamekasan Jl. Raya Panglegur km 04 Pamekasan \\ Email: erie@stainpamekasan.ac.id
}

\begin{abstract}
The emergence of thinking about the role of profession sharia advocate in the mediation of divorce cases that is derived from a fact produced by the judiciary in solving the case of divorce, which is almost $100 \%$ is a conventional decision that essentially have a pattern of win or lose. It is rare to find a win-win solution. Yet the most important is when the judiciary is not only referred to as deciding cases, but also solve the case. One of the alternatives presented in solving the divorce case is based on the win-win solution, The problem to be studied in this article is how the duty and responsibility of sharia advocate profession within the framework of maqahid al syariah. Where the task of sharia lawyers in general is the same as the non-sharia advocate task that is to defend public interest (public defender) and client in upholding justice. But what distinguishes it from non-sharia advocates is in providing defense, counseling, and being authorized for and on behalf of his clients sharia advocates based on the principle of helphelp, cling to the source of Islamic teachings. Second, the role of the advocate profession in the mediation of divorce cases should be submitted to a competent advocate, in this case is a sharia advocate. Advocates who have guidelines to always run their profession in accordance with the objectives of syara law (maqashid al syariah).
\end{abstract}

Munculnya pemikiran tentang peran profesi advokat syariah dalam mediasi perkara perceraian yaitu bermuara dari sebuah fakta yang dihasilkan oleh lembaga peradilan dalam menyelesaikan perkara perceraian, yaitu hampir 100\% merupakan putusan konvensional yang intinya bercorak menang atau kalah. Jarang sekali dijumpai penyelesaian berdasarkan konsep sama-sama menang 
(win-win solution). Padahal yang terpenting adalah ketika lembaga peradilan tidak hanya disebut sebagai memutus perkara, melainkan juga menyelesaikan perkara. Salah satu alternatif yang disuguhkan dalam menyelesaikan perkara perceraian adalah berdasarkan pada konsep sama-sama menang (win-win solution), Permasalahan yang akan dikaji dalam dari artikel ini adalah bagaimana tugas dan tanggung jawab profesi advokat syariah dalam kerangka maqahid al syariah. dimana tugas advokat syariah secara umum sama seperti tugas advokat non syariah yakni membela kepentingan masyarakat (public defender) dan kliennya dalam menegakkan keadilan. Namun yang membedakannya dengan advokat non syariah adalah dalam memberikan pembelaan, pendampingan, dan menjadi kuasa untuk dan atas nama kliennya advokat syariah berdasarkan pada prinsip tolong-menolong, berpegang teguh pada sumber ajaran agama Islam. Kedua, peran profesi advokat dalam mediasi perkara perceraian sebaiknya diserahkan pada advokat yang berkompeten, dalam hal ini adalah advokat syariah. Advokat yang mempunyai pedoman untuk selalu menjalankan profesinya sesuai dengan tujuan hukum syara (maqashid al syariah).

Keywords: profession, advocate; mediation; divorce; maqashid al shariah

\section{Pendahuluan}

Tujuan dari Negara Indonesia yang menganut sistem Negara hukum adalah untuk mencapai suatu kehidupan yang adil dan makmur bagi warganya, yang berdasarkan kepada Ketuhanan Yang Maha Esa. Salah satu usaha untuk mencapai tujuan tersebut adalah menempatkan masalah hukum pada kedudukan yang sesungguhnya, sesuai dengan aturan yang berlaku dalam suatu Negara. Dalam hal ini hukum di Negara Indonesia dijadikan suatu kaidah atau norma yang telah disepakati bersama dan karenanya harus dipertahankan dan ditaati bersama pula, baik oleh pemerintah maupun masyarakat dalam melaksanakan hak dan kewajiban masing-masing.

Selain itu, hukum tentu akan menghasilkan suatu profesi hukum. Profesi hukum ada yang menjalankan hukum itu sendiri. Begitu pula di Indonesia yang secara tegas menyatakan diri sebagai Negara hukum. Selama ini profesi hukum identik dengan proses pengadilan, atau profesi yang ada sangkut pautnya dengan peradilan seperti, hakim, jaksa, polisi, dan advokat atau pengacara. Para profesional hukum harus menjaga kepercayaan yang diberikan oleh klien serta tidak menyalahgunakan kewenangannya dan menjaga martabat profesi yang diembannya. Salah satu profesi hukum adalah advokat, sebagai warga yang hidup dalam aturan hukum tentu lelah mengetahui apa yang disebut dengan advokat (Pramudya dkk, 2010: 1-4). Kini profesi tersebut banyak diminati oleh para sarjana hukum. Negara hukum seperti Indonesia, 
penegakan hukum tidak bisa berdiri di atas satu kaki. Peran Negara, polisi, jaksa dan hakim hanyalah satu kaki penyangga. Satu kaki lainnya adalah peran masyarakat, terutama advokat. Konteks penegakan hukum, kehadiran advokat bukan semata-mata membela hak-hak kliennya. Justru yang paling penting terletak pada terciptanya peradilan yang adil dan keadilan yang merata. Ketentuan Pasal 5 Ayat (1) Undang-Undang Nomor 18 Tahun 2003 memberikan status kepada advokat sebagai penegak hukum lainnya dalam menegakkan hukum dan keadilan. Dalam kekuasaan yudikatif, advokat menjadi salah satu lembaga yang perannya sangat penting, selain peran dari instansi kepolisian dan kejaksaan. Kepolisian dan kejaksaan adalah lembaga yang mewakili kepentingan pemerintah, sedangkan advokat mewakili kepentingan masyarakat (Pramudya dkk., 2010: 1-4).

Advokat merupakan salah satu profesi bantuan hukum yang kehadirannya dalam persidangan di pengadilan diharapkan dapat membantu hakim dalam mencari kebenaran. Bantuan hukum yang diberikan oleh seorang advokat merupakan sebagian sarana menegakkan hukum itu sendiri, terutama untuk memperoleh kebenaran dan keadilan, dimana justisiabelen akan mendapat perlindungan dan kepastian hukum dalam beracara di pengadilan. Masalah bantuan hukum tentu tidak bisa dilepaskan dengan lembaga peradilan, karena proses peradilanlah yang menyebabkan dapat berperannya bantuan hukum secara nyata. Proses peradilan ini berjalan dilakukan oleh pengadilan dengan segala perangkatnya, proses ini diatur dalam suatu peraturan hukum yang lazim disebut hukum acara. Dalam beracara tentu advokat telah memahami prosedur beracara di pengadilan baik secara hukum maupun praktek, termasuk jalan keluar yang akan ditawarkan terhadap pihak yang berperkara sebelum dilanjutkan dalam proses pemeriksaan, artinya seorang advokad diharapkan mampu untuk ikut serta dalam melakukan mediasi untuk kebaikan pihakpihak yag berperkara (Abdul Manan: 2006, 68-70).

Konsep hukum Islam, manusia kedudukannya sama di depan hukum dan berhak mendapat jaminan keadilan. Pemenuhan hak dan kewajiban hukum menjadi tesis bagi tercapainya tujuan keadilan hukum itu sendiri. Namun yang perlu digarisbawahi adalah otoritas pembuat hukum mutlak berada ditangan Allah, sedangkan penguasa dan rakyat hanya diberikan amanat untuk menyelesaikan urusan publik bersumber pada wahyu dan selebihnya ditentukan oleh manusia sendiri melalui ijtihad berdasarkan konsep musyarawah. Implikasinya segala proses penegakan hukum dantujuan diberlakukannya hukum hendaknya ditujukan untuk keadilan dan kemaslahatan manusia dengan 
tidak mengabaikan ketentuan syara. Konsep paling populer dalam penegakan hukum Islam adalah teori hukum syara (maqashid al syariah). Sehingga lahirlah organisasi bantuan hukum yang sejalan dengan tujuan syara yakni adanya APSI (Asosiasi Pengacara Indonesia) atau yang biasa dikenal advokat syariah yang akan memberikan bantuan hukum sesuai tuntunan syara.

Harus diakui, bahwa mendamaikan para pihak yang sedang berperkara di pengadilan bukanlah pekerjaan yang mudah, apalagi dalam perkara perceraian sentimen pribadi lebih mengemuka dibandingkan pokok persoalan yang sebenarnya. Banyak faktor yang dapat menghambat keberhasilan menuju perdamaian, diantara sekian banyak faktor tersebut, salah satunya adalah kurang tersedianya pranata hukum yang dapat membantu para pihak dalam memilih metode yang tepat bagi penyelesaian sengketa (Adiyono, 2013: 130-131).

Hal ini tentu membutuhkan penyelesaian yang efektif dan tidak berkepanjangan, sehingga dalam mewujudkan tujuan peradilan yang sederhana, cepat dan biaya ringan yang termaktud dalam Pasal 2 Ayat (4) Undang-Undang Nomor 48 Tahun 2009 tentang Kekuasaan Kehakiman (Adiyono, 2013: 137). Mahkamah Agung sebagai penyelenggara peradilan tertinggi di Indonesia mulai menggagas beberapa metode untuk mempersingkat proses penyelesaian sengketa di pengadilan, namun dapat memberikan hasil yang lebih optimal. Salah satu gagasan yang cukup progresif antara lain dengan mengoptimalkan lembaga mediasi pada perkara-perkara perdata. Hal mana dimaksudkan agar para pihak yang berperkara tidak harus menempuh seluruh tahapan proses persidangan.

Mediasi merupakan salah satu alternatif penyelesaian sengketa (APS) yang menggunakan pendekatan win-win solution dengan proses dan cara yang lebih sederhana dalam rangka memberikan akses keadilan yang lebih memuaskan kepada para pihak dengan bantuan seorang mediator sebagai penampung aspirasi dalam upaya menemukan penyelesaian sengketa yang terbagi bagi kedua belah pihak (Witanto, 2011: 24). Hal ini sejalan dengan ajaran Islam yang menganjurkan adanya juru damai dalam upaya mendamaikan perselisihan, firman Allah dalam al Quran menyatakan:

"Dan jika kamu khawatirkan ada syiqaq (persengketaan) antara keduanya, maka kirimlah seorang hakam dari keluarga laki-laki dan seorang hakam dari keluarga perempuan. Jika kedua hakam itu bermaksud mengadakan perbaikan, niscaya Allah memberi taufik kepada suami istri itu. Sesungguhnya Allah Maha Mengetahui lagi Maha Mengenal" (QS. An Nisa: 35). 
Kenyataan praktik yang dihadapi, jarang dijumpai putusan perdamaian. Produk yang dihasilkan peradilan dalam penyelesaian perkara yang diajukan kepadanya, terutama dalam perkara perceraian hampir 100\% berupa putusan konvensional yang bercorak menang atau kalah. Jarang ditemukan penyelesaian penyelesaian berdasarkan konsep sama-sama menang (win-win solution). Berdasarkan fakta ini kesungguhan, kemampuan, dan dedikasi hakim untuk mendamaiakan boleh dikatakan sangat mandul. Ada yang berpendapat, kemandulan itu bukan semata-mata disebabkan faktor kurangnya kemampuan, kecakapan, dan dedikasi hakim, tetapi lebih didominasi motivasi dan peran advokat atau kuasa hukum. Mereka lebih cenderung mengarahkan proses litigasi berjalan terus menerus hingga tahap putusan, demi mengejar professional fee yang besar dan berlanjut (Harahap, 2012: 241). Advokat diharapkan dapat berperan sebagaimana mestinya dalam menegakkan keadilan baik dalam proses litigasi maupun non litigasi. konsep bantuan hukum dalam proses penegakan hukum Islam di Peradilan Agama hampir sama dengan yang dilakukan di lembaga peradilan lainnya. Hal terpenting dari praktik bantuan hukum di Pengadilan Agama terletak pada keharusan menerapkan prinsip-prinsip dan asas-asas penegakan hukum Islam yang sesuai dengan tujuan syariat (maqashid al syariat) (Handayani, 2015: 63).

Dalam penelitian ini penulis menggunakan metode penelitian pustaka atau yang biasa dikenal sebagai library research, yaitu dengan cara mengkaji sumber kepustakaan yang dalam hal ini berupa literature, buku-buku, kitab-kitab, dan dokumen yang berkaitan dengan pembahasan penelitian ini (Suryabrata, 2005: 75). Penelitian ini bersifat deskriptif-analitik yaitu menggambarkan secara obyektif tentang obyek penelitian peneliti dengan cara mengumpulkan data-data, kemudian menganalisa dengan kerangka pemikiran yang telah disusun dengan cermat dan terarah dan dengan tujuan untuk mengetahui dan menjelaskan obyek penelitian (Soejono dkk., 2003: 20-21).

Sedangkan jenis penelitian ini menggunakan content analysis (analisis isi) yaitu analisis aktivitas atau mengumpulkan dan menganalisis informasi, yakni dengan menganalisa dokumen-dokumen yang berkaitan langsung dengan Peran Advokat dalam Upaya Mediasi Perkara Perceraian. Peran advokat syariah sangat dibutuhkan. Sebab dalam menyelesaikan perkara perceraian tidak butuh sembarang orang untuk menjalankan fungsi hakam atau mediator. Melainkan butuh orang atau hakam yang benar-benar mempunyai kompetensi khusus yakni advokat syariah. 


\section{Peran Advokat Syariah Dalam Melakukan Mediasi}

Perjalanan advokat Indonesia dalam membentuk suatu wadah organisasi advokat sungguh terjal dan mendaki. Sejarah mencatat bersatunya para advokat selalu diikuti dengan perpecahan. Kewibawaan advokat Indonesia jatuh, bangun, dan kemudian jatuh lagi. Sejarah perjalanan panjang pergulatan menuju suatu wadah organisasi advokat Indonesia telah dilalui cukup lama, hingga para advokat dapat bercermin dan beranjak ke arah yang lebih baik mulai dari pahit manisnya hingga pendakian keras yang melelahkan.

Dalam lintas sejarah organisasi bantuan hukum di Indonesia dikenal beberapa organisasi advokat mulai dari Belie van Advocaten yang menjelma menjadi Persatuan Advokat Indonesia (PAI) dan sekaligus menjadi cikal bakal untuk membentuk dan mendirikan Persatuan Advokat Indonesia (PERADIN). Kemudian atas prakarsa pemerintah untuk mempersatukan advokat membentuk wadah tunggal dengan nama Ikatan Advokat Indonesia (IKADIN). Organisasi ini tetpecah belah hingga berdirinya Asosiasi Advokat Indonesia (AAI) dan Ikatan Penasihat Hukum Indonesia (IPHI). Seolah tak ada akhir, perpecahan di tubuh organisasi induk advokat kembali terjadi hingga berdiri Himpunan Advokat dan Pengacara Indonesia (HAPI) dan berdiri juga Serikat Pengacara Indonesia (SPI), Asosiasi Konsultan Hukum Indonesia (AKHI), Himpunan Konsultan Hukum Pasar Modal (HKHPM) dan Asosiasi Pengacara Syariah Indonesia (APSI).

Namun, keberadaan Asosiai Pengacara Syariah Indonesia (APSI) sebagai perhimpunan sarjana syariah yang berprofesi sebagai advokat belum begitu eksis karena merupakan wajah baru dalam PERADIN. Secara umum keberadaan advokat/pengacara yang terhimpun dalam APSI juga berprofesi seperti halnya advokat/pengacara pada umumnya. Keberadaan mereka kemudian diakui untuk memberikan jasa konsultasi dan bantuan hukum kepada masyarakat yang berperkara di linkungan Peradilan Agama. Karena dalam UU Nomor 7 Tahun 1989 diberikan ruang kepada pihak advokat/pengacara untuk mendampingi, membantu, dan/atau mewakili kliennya di Pengadilan Agama.

Advokat yang berpraktek di lingkungan peradilan umum memiliki kewenangan yang sama dengan advokat yang akan berpraktek di lingkungan pengadilan agama. Akan tetapi yang menjadi titik perbedaan adalah tentang jenis perkara yang menjadi kewenangan peradilan agama itu sendiri. Kewenangan menangani perkara perdata untuk umat Islam adalah salah satu kewenangan pengadilan agama. Untuk itu advokat yang berpraktek di lingkungan pengadilan agama berkewajiban membekali diri dengan pengetahuan yang berhubungan 
dengan perkara yang menyangkut hukum-hukum syariah (Handayani, 2015: 77).

Keberadaan organisasi Advokat Syariah (APSI) yang tergabung dalam PERADIN meskipun belum eksis sepenuhnya, tetapi masih memiliki komitmen kuat dalam memberikan jasa bantuan hukum. APSI mengikuti arah bantuan hukum di Indonesia dilakukan proses pengadilan data dan informasi melalui dua tahapan yakni penyebaran kuesioner kepada pihak-pihak yang kompeten dan melakukan diskusi grup (group discussion). APSI juga membangun kemitraan dengan lembaga-lembaga advokat dan bantuan hukum yang bernaung di bawah Fakultas Syariah dan Hukum pada pendidikan tinggi, selain itu APSI juga membangun relasi dengan wadah organisasi sosial kemasyarakatan. Seiring perkembangannya, eksistensi APSI kini telah berkembang pesat di Indonesia. APSI turut bekerjasama dengan YLBHI yang setiap tahun rutin menggelar legal aid training bagi kalangan mahasiswa, yakni karya latihan bantuan hukum (Kusnadi, 2011: 144-155).

\section{Peran Advokat dalam Mediasi Perkara Perceraian}

Dalam suatu sengketa antara dua pihak atau beberapa pihak, maka dapat diupayakan untuk perdamaian atau dilakukan upaya mediasi. Perdamaian dapat dilakukan di luar pengadilan dan di dalam pengadilan (Kussunaryatun, 2010: 34). Tanpa mengurangi arti perdamaian dalam segala bidang persengketaan, makna perdamaian dalam sengketa perceraian mempunyai nilai keluhuran tersendiri. Dengan dicapainya perdamaian antata suami istri dalam sengketa perceraian, bukan keutuhan rumah tangga saja yang dapat diselamatkan tetapi juga kelanjutan pemeliharaan anak dapat dilaksanakan sebagaimana mestinya, agar fungsi mendamaikan dalam perkara perceraian ini dapat dilakukan secara efektif dan optimal, maka sedapat mungkin hakim atau mediator menemukan hal-hal yang melatarbelakangi dari persengketaan yang terjadi (Mustaming, 2014:13).

Dalam hal sengketa perceraian karena alasan percekcokan dan pertengkaran secara terus-menerus, peranan hakim atau mediator sangat diharapkan untuk mencari faktor-faktor penyebab dari perselisihan dan pertengkaran itu. Apabila hal ini sudah diketahui oleh hakim atau mediator, maka dengan mudah para hakim atau mediator tersebut mengajak dan mengarahkan para pihak yang berselisih itu untuk berdamai dan rukun kembali seperti sediakala. Sehubungan dengan hal ini, seorang hakim atau mediator harus terpanggil hati nuraninya secara optimal untuk mengusahakan perdamaian, tidak hanya 
terjebak pada usaha mencari fakta kualitas perselisihan itu sendiri sedangkan ia tidak mengetahui faktor apa yang melatarbelakangi pertengkaran itu. Apalagi kalau para hakim atau mediator dalam mengusahakan perdamaian yang demikian itu tidak akan mendatangkan hasil yang bermanfaat kepada kedua belah pihak yang bersengketa (Hariyanto, 2017: 34).

Dalam masalah perceraian tindakan hakim atau mediator dalam mendamaikan para pihak yang bersengketa adalah untuk menghentikan persengketaan dan mengupayakan agar perceraian tidak terjadi. Apabila upaya perdamaian tersebut berhasil, maka gugatan perceraian yang diajukan ke pengadilan oleh para pihak itu dengan sendirinya harus dicabut. Terhadap ketentuan ini tidak dibuat akta perdamaian karena tidaklah mungkin dibuat suatu ketentuan yang melarang seseorang melakukan perbuatan tertentu, misalnya melarang salah satu pihak meninggalkan tempat tinggal bersama, melarang salah satu pihak melakukan penganiayaan dan sebagainya (Mannan, 2006: 164-165).

Menurut Christopher W. Moore mediator memiliki 3 tipe, antara lain: pertama mediator otoritatif dalam proses mediasi terdapat beberapa komponen yang terlibat langsung, yaitu para pihak yang bersengketa (penggugat-tergugat) dan mediator. Ketiga komponen tersebut akan terlibat dalam satu proses interaksi secara timbal balik berdasarkan kepentingan dan pengaruh-pengaruh tertentu. Proses interaksi dan komunikasi bisa terjalin secara teratur dengan panduan penuh mediator atau secara acak di luar kendali mediator. Seorang mediator yang memiliki tipe otoritatif akan mampu mengendalikan komunikasi bahkan dalam beberapa hal dia mampu untuk mempengaruhi hasil akhir dari proses mediasi yang dibangun. Posisi yang dimiliki oleh seorang mediator otoritatif sangat kuat sehingga para pihak terkadang menunjukkan sikap pasrah untuk menyerahkan penyelesaian yang terbaik kepada sang mediator. Kedua, mediator social network mediator yang lahir karena proses hubungan/ jaringan sosial atau karena sama-sama berasal dari suatu komunitas tertentu, pada umumnya memiliki keterlibatan secara emosional dengan para pihak. Hubungan sosial terjalin dari berbagai aspek, misalnya karena faktor kelompok dan organisasi tertentu.

Tipe mediator berdasarkan hubungan sosial memiliki kelebihan antara lain lebih mudah untuk menciptakan pola komunikasi yang baik dengan para pihak, karena antara mediator dengan para pihak memiliki karakter dan ciri khas sosial yang sama. Ketiga mediator independent mediator independen merupakan mediator yang sama sekali tidak memiliki keterikatan apapun 
dengan para pihak, baik karena pribadinya maupun karena sengketa yang sedang dihadapi. Tipe mediator independen ini merupakan tipe yang paling cocok bagi proses perdamaian yang dilakukan dalam proses berperkara di pengadilan, mengingat sifatnya yang independen dan profesional. Mediator independen akan lebih memberikan kenyamanan bagi para pihak dalam mengekspresikan kepentingan-kepentingan kristis pada saat melakukan proses negosiasi dan perundingan (Witanto, 2011: 97-99).

Mediator menurut Fuller memiliki beberapa fungsi, antara lain: Sebagai Katalisator, Fungsi mediator sebagai katalisator harus mampu menciptakan keadaan dan suasana baru dari sebuah pertentangan kearah kondisi koomperatif dalam forum kebersamaan. Tidak terpenting bagi mediator untuk mengetahui siapa yang benar dan siapa yang salah, dan tidak pula untuk mempertajam perbedaan itu dalam forum perundingan. Sebagai Pendidik, Mediator harus mampu menjadi seorang pendidik (educator), yang mampu memberikan arahan dan nasihat menyangkut sikap-sikap yang baik dalam menyelesaikan masalah, mediator harus berusaha untuk memahami kehendak, aspirasi, prosedur kerja, keterbatasan politis dan kendala usaha dari para pihak (Hariyanto, 2016: 69-70).

Sebagai penerjemah hal terpenting dari peranan mediator sebagai seorang penerjemah adalah ketika masing-masing pihak menyampaikan usulan dan konsep penawaran, maka mediator harus mampu untuk menerjemahkan keinginan-keinginan yang terkandung dalam konsep tersebut kepada pihak lain dengan bahasa dan penyampaian yang lugas dan mudah untuk dimengerti. Ketika salah satu pihak mengambil keputusan untuk sedikit mengalah, maka pihak tersebut harus memahami akibat dari keputusan yang diambilnya itu, sehingga tidak terjadi miss understanding terhadap pengambilan keputusan terpenting dalam proses perundingan.

Sebagai narasumber fungsi mediator sebagai narasumber bukan berarti bahwa mediator harus serba mengerti, namun setidaknya mediator harus mampu mendaya gunakan atau melipat gandakan kemanfaatan sumbersumber informasi yang tersedia. Berkaitan dengan hal itu, maka mediator harus menguasai prosedur dan mekanisme yang berlaku sekaligus memahami tentang materi sengketa yang sedang dihadapi. Walaupun fungsi pokok mediator berbeda dengan penasihat hukum, namun setidaknya mediator dapat memberikan solusi dan penjelasan secukupnya mengenai persoalanpersoalan yang dihadapi.

Sebagai penyandang berita jelek menjadi pihak yang berada ditengah- 
tengah orang yang sedang bersengketa tentunya akan banyak menerima risiko menyangkut datangnya informasi-informasi yang menyudutkan, baik yang bertujuan untuk memancing emosi maupun hanya sekedar sebagai alat untuk menggertak pihak lawan melalui perantaraan mediator. Dalam kaitannya dengan fungsi mediator sebagai penyandang berita jelek, mediator harus siap untuk mengantisipasi dan mencari solusi atas semua aksi dan reaksi negatif yang disampaikan oleh para pihak. Berbagai jenis informasi harus diinvertarisir dan dinetralisasi dengan pola komunikasi yang baik, latar belakang sengketa yang bertedensi sentiment pribadi merupakan persoalan yang paling dominan dalam membentuk perang propaganda. Mediator tidak boleh terpancing untuk hanyut dalam pertengkaran para pihak, namun justru harus mampu membalikkan situasi menjadi kondusif dan terarah (Hariyanto, 2017: 37).

Sebagai Agen Realitas Ketika dilakukan kaukus akan banyak didapatkan informasi yang bersifat realitas, hal itu harus dikemas menjadi bahan acuan dalam mengelola proses tawar-menawar dan kompromi. Fungsi mediator sebagai agen realitas dapat dilakukan jika mediator dapat menjadi pendengar yang baik dalam proses interaksi verbal. Selain dari pernyataan secara lisan, kondisi realitas dapat disampaikan melalui tulisan-tulisan yang dapat memberikan gambaran tentang sebuah kenyataan.

Sebagai Kambing Hitam dalam setiap konsep usulan yang diajukan oleh para pihak tidak semuanya dapat diakseptasi oleh pihak lawan dengan mudah, namun terkadang menimbulkan penolakan dan ketidakpuasan yang kesemuanya itu bisa ditumpuhkan kepada mediator. Kondisi seperti ini harus disadari oleh seorang mediator dengan terus berusaha mengubah siasat melalui beberapa tawaran opsi yang telah dipersiapkan. Mediator juga harus menjaga agar dalam proses interaksi para pihak tidak terlibat perdebatan kusir yang tidak memiliki fungsi untuk mengakhiri sengketa. Strategi tertentu harus digunakan oleh mediator agar para pihak mau menumpahkan segala reaksi negatif kepadanya dan memproyeksikan setiap reaksi positif terhadap pihak lawan perkaranya (Hariyanto, 2016: 69-70).

\section{Mediasi dalam Perkara Perceraian Perspektif Hukum Islam}

Mediasi dalam perkara perceraian telah dijelaskan di dalam al Quran: "Dan jika kamu khawatirkan ada syiqaq (persengketaan) antara keduanya, maka kirimlah seorang hakam dari keluarga laki-laki dan seorang hakam dari keluarga perempuan. Jika kedua hakam itu bermaksud mengadakan perbaikan, niscaya Allah memberi taufik kepada suami istri itu. Sesungguhnya Allah Maha Mengetahui lagi Maha Mengenal" (QS. an Nisa: 35). 
Jika suami istri silih berganti berselisih, antara keduanya menguatkan perbedaan dan salah satunya tidak turun dari kesombongandan kemuliaannya, serta tidak mengikuti berbagai langkah untuk mendekati satu sama lain dan membuat kesepakatan. Keadaan tersebut sangat genting karena dapat mengancam kehidupan keluarga sehinggga diperlukan pertolongan dari pihak luar untuk mendatangi keduanya. Hendaknya dipilih dari pihak yang mendamaikan keduanya memiliki kebaikan dan perbaikan untuk ikut campur tangan dengan mereka. Hal tersebut dikuatkan pada kedua pihak. Mereka adalah yang diharapkan ikut capur untuk tujuan kebaikan dan perbaikan serta jauh dari sifat kesombongan dan kefanatikan dengan melihat segi kemaslahatan pada diri suami istri.

Kemudian dua penengah, yaitu dari keluarga suami dan keluarga istri berkumpul bersama untuk membahas berbagai penyebab perselisihan dan mengobatinya. Kedua pihak berusaha memalingkan berbagai pandangan demi kesederhanaan, membimbing hati untuk konsisten serta menyerahkannya kepada Allah, jika berhasil mendamaikan mereka dan perbuatannya benar.

Pertimbangan dipilihnya dua penengah dari keluarga suami dan keluarga istri, karena mereka adalah orang yang sangat mengharapkan kebahagiaan keluarga dengan menyesuaikan hubungan kekerabatan dari suami istri. Disamping itu, mereka juga orang-orang yang sangat menginginkan untukmemelihara sesuatu yang terkadang menjadi penyebab perselisihan dan permasalahan yang harus ditutupi dan disembunyikan sehingga tidak mempengaruhi kedudukan suami istri (Ali, 2012: 322-323). Dengan ketetapan ini, al Quran menjelaskan pengobatan dalam keadaan pertentangan dan perselisihan yang parah, kelemahan suami istri terhadap diri mereka dengan menghilangkannya.

Teks yang tertulis pada ayat di atas memberikan persyaratan pada dua penengah yang terdiri dari para kerabat. Berdasarkan ini pula untuk jalan kewajiban. Dengan ini al Qurthubi memilih pendapat dalam tafsirnya yang dikutip dalam Fiqih Keluarga, lalu ia berkata dua keputusan tidak bisa terjadi kecuali dari keluarga laki-laki dan perempuan karena mereka lebih mengetahui keadaan suami istri. Kedua penengah teramasuk keluarga yang memiliki keadilan, berpikiran, dan berpandangan baik secara hukum fiqih. Jika keluarga keduanya tidak dijumpai maka yang baik pada masalah itu adalah mengutus dari selain mereka berdua orang alim yang adil. Hal itu jika urusan keduanya menjadi rumit dan tidak diketahui siapa yang bersalah dari keduanya. Adapun jika diketahui ada penganiaya dari pihak lain maka ia dihukum dengan benar 
untuk pemiliknya dan memaksanya untuk menghilangkan gangguan.

Sebagian meraka ada yang membawa hal ini sebagai anjuran. Oleh karena itu, Syaikh Muhammad Ali ash Shabuni yang dikutip dalam Fiqih Keluarga mengatakan bahwa teks tertulis ayat di atas memberikan persyaratan dalam dua keputusan agar keduanya berasal dari para kerabat berdasarkan firman Allah "putuskanlah dari keluarga suami dan putuskanlah dari keluarga istri" bahwa hal ini pada jalan kewajiban, akan tetapi ulama memilih pendapat sebagai anjuran dan mereka mengatakan bahwa seorang hakim mengutus penengah dari orang lain diperboehkan, karena fungsi penengah ini untuk mengetahui keadaan suami istri dan melaksanakan kebaikan antara keduanya. Disamping itu juga untuk memperoleh kesaksian atas orang yang zalim dari keduanya. Tujuan tersebut sebagaimana dilakukan kerabat dekat. Hanya saja para kerabat lebih mengetahui keadaan suami istri. Mereka diminta untuk memperbaiki dengan bantuan orang lain agar menjauhkan prasangka dengan kecondongan pada salah satu pihak dari suami istri.

Al alusi telah bersepakat dengannya, lalu ia mengatakan, dikhususkan bagi keluarga dekat karena mereka lebih menginginkan perbaikan, lebih mengetahui keadaan yang terjadi, dan lebih mengarahkan keduanya (suami istri) untuk mencintai, jika hal tersebut dapat terwujud dengan bantuan orang lain yang memahami keadaan keduanya maka ini diperbolehkan. Al Jashash mengatakan bahwa sesungguhnya perintah Allah dengan adanya salah satu penengah dari keluarga istri dan yang lain dari keluarga suami agar ia tidak mendahului seorang yang berprasangka, jika keduanya dari orang lain yang condong pada salah satunya. Oleh karena itu, salah seorang mereka dari suami dan yang lain dari istrinya sehingga hilanglah dugaan atau prasangka dari masing-masing mereka.

\section{Pemberi Bantuan Hukum dalam Islam}

Keberadaan mediator untuk menyelesaikan sengketa keluarga sangat urgen, karena peran mediator memperbaiki hubungan suami istri akan menentukan kelanggengan suatu rumah tangga. Terutama ketika sudah menunjukkan tanda-tanda adanya perselisihan maka dapat mengutus mediator (Abbas, 2011: 192).

Konsepsi pemberi jasa hukum dalam Islam berbeda dengan konsepsi pemberianjasa hukum positif. Sebab dalam hukum Islam, konsep pemberian jasa hukum terbagi atas tiga (3) bagian, yaitu hakam, mufti, dan mushalailahalailah. Sementara itu, konsep pemberian jasa hukum dalam hukum positif 
tidak membedakannya dalam tiga kategori, tetapi yang ada hanya pemmbagian dari segi pemberian nama semata, misanya advokat, IPHI, dan sebagainya. Ketiga pemberian jasa bantuan hukum Islam tersebut sama halnya seperti advokat, pengacara, arbiter, dan kunsultan hukum, atau penasiahat hukum yang berperan sebagai pemberi jasa hukum. Jasa hukum yang diberikan berupa knnsultasi, menjalankan kuasa, mewakili, mendampingi, membela dan melakukan tindakan hukum lain bagi klien untuk menyelesaikan perselisihan, mendamaikan sengketa atau memberi nasihat kepada para pihak agar saling melaksanakan kewajiban dan mengebalikan haknya kepada pihak lain secara islah. Untuk lebih jelasnya akan diuraikan sebagai berikut:

Hakam Secara etimologis, dalam pengertian bahasa Arab, tahkim berasal dari kata kerja hakkama-yuhakkimu-tahkiman; berarti menjadi penengah bagi suatu sengketa. Sementara itu menurut pengertian terminologis fikih, tahkim diartikan sebagai dua orang atau lebih men-tahkim-kan kepada seorang diantara mereka untuk menyelesaikan sengketa dan diterapkan hukum syara atas sengketa mereka itu (Supriadi, 2014: 153-154).

Pendapat lain menyatakan bahwa pada Peradilan Agama yang ada di Indonesia terdapat dua pendapat dalam masa mengartikan kata hakam. Yang pertama banyak dianut adalah mengartikan hakam denganarti wakil, kemudian pendapat kedua mengartikan kata hakam sebagai hakim. Mahkamah Islam tinggi juga mengakui kedua pendapat tersebut dalam putusannya 12 Januari 1939 Nomor 3, dan tanggal 10 Maret 1951 Nomor 6 (Abidin dkk., 1999: 188).

Dalam kaitannya dengan pemberian jasa bantuan hukum yang diberikan oleh hakam, seorang hakam dalam menyelesaikan tugasnya akan selalu berpedoman pada sumber-sumber hukum yang dijadikan patokannya. Oleh karena itu, sumber hukum yang dijadikan patokan adalah al Quran dan sunnah maupun Ijma Ulama. Al Quran sebagai sumber hukum Islam yang pertama memberikan petunjuk kepada manusia agar apabila terjadi sengketa antara para pihak dapat dselesaikan secara islah. Sesuai dengan Firman Allah dalam surah an Nisa ayat 35.

Rahmat Rosyadi dan Sri Hartini mengatakan bahwa berdasarkan tugas hakam, maka dapat menjelaskan fungsinya sebagai hakam dalam memberikan bantuan hukum, nasihat hukum, arbitrase hukum, atau arbitrase untuk melakukan islah. Fungsi hakam adalah berusaha mendamaiakan para pihak yang bersengketa agar masalah dapat diselesaikan secara damai dan kekeluargaan. (Supriadi, 2016: 154-161). 


\section{Mufti}

Secara etimologis, mufti diartikan sebagai orang yang memberikan fatwa. Fatwa (legal advice) ialah jawaban atas sesuatu pertanyaan yang tidak begitu jelas hukumnya. Mufti menurut pengertian terminologis adalah orang yang dipercayakan kepadanya hukum-hukum Allah untuk disampaikan kepada manusia. Oleh karena itu, kelembagaan mufti adalah orang yang memberikan fatwa yang lazim disebut Ifta. Dalam perspektif hukum nasonal, mufti sama dengan penasihat hukum atau konsultan hukum.

Dalam tataran konsep hukum nasional, keberadaan mufti yang perannya sama dengan konsultan hukum atau penasihat hukum, tugas pokoknya memberikan nasihat hukum kepada orang atau masyarakat yang sangat membutuhkannya. Dengan demikian, mufti memberikan fatwa kepada seseorang terhadap sesuatu hal yang telah terjadi. Yang dimaksud dengan suatu hal, yaitu segala peristiwa hukum kejadian atau perkara yang sudah terjadi dalam kehidupan manusia. Putusan seorang mufti disebut fatwa dan ia hanya berlaku pada seorang yang meminta fatwa, tetapi tidak mengikat.

Selain sumber hukum yang berasal dari al Quran, sumber hukum fatwa lainya bersumber dari as Sunnah, sebagaimana Rasulullah SAW mengatakan bahwa addin an nasihah; agama itu adalah nasihat. Keberadaan seorang mufti dalam rangka memberikan jasa hukum kepada masyarkat merupakan suatu yang sangat dibutuhkan, akan tetapi dalam memberikan advice-nya, seorang mufti tetap mendapatkan pengawasan dari pemerintah. Menurut Rahmat Rosyadi dan Sri Hartini, pengawasan dalam segala hal sangat dibutuhkan dalam rangka meningkatkan kinerja suatu profesi sebagai mufti.

\section{Mushalailah-alailah}

Secara etomologis, kata mushalih berasal dari akar kata ash-shulhu-yashilhumushalih. Ash Shulhu artinya memutus pertengkaran atau perselisihan. Sementara pengertian terminologisnya adalah suatu jenis akad untuk mengakhiri perlawanan antara dua orang yang berlawanan. Melakukan akad (perjanjian) adalah merupakan hak setiap orang dan dapat dibenarkan apabila perjanjian itu dalam hal yang baik. Pada hakikatnya, perjanjian biasanya dilakukan oleh orang atau kelompok orang terhadap suatu masalah yang disepakati. Perjanjian tidak dapat dibatalkan kecuali oleh kedua pihak yang melakukan perjanjian. Pembatalan perjanjian oleh salah satu pihak baik disengaja atau tidak merupakan pelanggaran. Akan tetapi dalam kenyataan tidak semua orang dapat menepati perjanjian; pihak yang satu menepati perjanjian, pihak yang lain melakukan 
pelanggaran atau melakukan wanprestasi atau perlawanan. Dengan demikian, akan timbul perlawanan dari pihak lain sehingga menjadi suatu perselisihan atau persengketaanantara para pihak yang melakukan perjanjian.

Dalam perspektif Islam, subjek atau para pihak yang melakukan perjanjian disebut mushalih. Perkara yang menjadi objek perselisihan atau persengketaan disebut mushalih anhu. Pihak-pihak yang memberi jasa hukum dalam menyelesaikan persengketaan disebut mushalih alaihi atau badalush shulhu.

Mendamaikan para pihak merupakan kewajiban dan merupakan pekerjaan mulia (Supriadi, 2014:167). Sumber hukumnya yaitu firman Allah dalam al Quran:

"Dan apabila dua golongan orang yang beriman bertengkar, damaikanlah mereka. Akan tetapi, jika salah satu kedua (golongan) berlaku aniaya (melanggar hak) terhadap yang lain, maka perangilah orang yang menganiaya sampai kembali ke jalan Allah. Akan tetapi, apabila ia telah kembali damaikan keduanya dengan adil, dan bertindaklah benar, sungguh Allah cinta kepada orang-orang yang berlaku adil" (QS. al Hujurat: 9).

Bertitik tolak dari ketentuan ayat di atas, Allah telah mengisyaratkan kepada manusia, apabila terjadi perselisihan atau pertengkaran atau pertengkaran antara para pihak, maka jalan yang perlu ditempuh adalah harus melakukan upaya perdamaian. Oleh karena itu, apabila diantara para pihak ada yang melakukan pelanggaran atau wanprestasi dalam perjanjian tersebut, pihak yang melakukan pelanggaran harus mendapat sanksi hukum yang tegas. Sanksi hukum yang patut diberikan adalah melaksanakan kewajiban atau mengembaikan hak orang lain yang dirampasnya. Dengan demikian, apabila pihak yang telah melanggar hak orang lain tersebut telah memenuhi kewajibannya, maka diupayakan untuk mendamaikan kembali secara adil dan benar sesuai asas keadilan (Supriadi, 2016: 167).

\section{Profesi Advokat Syariah dan Implementasi maqashid al syariah}

Tujuan syara sering disebut dengan maqashid al syariah. Secara global, tujuan syara dalam menetapkan hukum-hukumnya adalah untuk kemaslahatan manusia seluruhnya, baik kemaslahatan di dunia yang fana ini, maupun kemaslahatan di hari yang kekal (Syah, 1999: 6). Maqashid al syariah bermaksud mencapai, menjamin dan melestarikan kemaslahatan bagi umat manusia, khususnya umat Islam. Untuk ini dicanangkan tiga skala priioritas yang berbeda tetapi saling melengkapi, yaitu: 
Pertama Maqashid al daruriyyat (tujuan-tujuan primer), didefinisikan sebagai tujuan yang harus ada, yang ketiadaanya akan berakibat menghancurkan kehidupan secara total. Di sini ada lima kepentingan yang harus dilindungi, yaitu: agama, jiwa, akal, harta dan keturunan. Kedua Maqashid al hajiyyat (tujuan-tujuan sekunder), didefinisikan sebagai sesuatu yang dibutuhkan oleh manusia untuk mempermudah mencapai kepentingan-kepentingan yang termasuk dalam kategori al daruriyyat. Sebaliknya, menyingkirkan faktor-faktor yang mempersulit usaha perwujudan al daruriyyat. Karena fungsinya yang mendukung dan melengkapi tujuan primer, maka kehadiran tujuan sekunder ini dibutuhkan (sebagai terjemah harfiah dari kata hajiyyat), bukan niscaya (sebagai terjemah langsung dari kata al daruriyyat). Artinya jika hal-hal hajiyyat tidak ada, maka kehidupan manusia tidak akan hancur, tetapi akan terjadi berbagai kekurang sempurnaan, bahkan kesulitan.

Ketiga Maqashid al tahsiniyyat,didefinisikan sebagai sesuatu yang kehadirannya bukan niscaya dan bukan dibutuhkan, tetapi bersifat akan memperindah (sebagai terjemah harfiah dari kata al tahsiniyyat) proses perwujudan kepentingan al daruriyyat dan hajiyyat. Sebaliknya, ketidakhadirannya tidak akan menghancurkan maupun mempersulit kehidupan, tetapi mengurangi rasa keindahan dan etika (Wahyudi, 2007: 45-47). Apabila dilihat secara lebih terperinci Maqashid al daruriyyat adalah Memelihara kemaslahatan agama. Agama adalah suatu yang harus dimiliki oleh manusia supaya martabatnya terangkat lebih tinggi dari martabat mahluk yang lain, dan juga untuk memenuhi hajat jiwanya. Agama Islam merupakan nikmat Allah yang tertinggi dan sempurna seperti yang dinyatakan dalam al Quran:

"Pada hari itu telah Kusempurnakan agamamu dan telah pula Kusempurnakan nikmat-Ku atasmu, dan Aku telah rela Islam itu menjadi agama buat kamu" (QS. al Maidah: 3).

Memelihara jiwa Untuk tujuan ini, Islam melarang pembunuhan dan pelaku pembunuhan diancam dengan hukuman qisas (pembalasan yang seimbang), sehingga dengan demikian diharapkan agar orang sebelum melakukan pembunuhan, berpikir sepuluh kali, karena apabila orangyangdibunuh itu mati, maka si pembunuh juga akan mati atau jika orang yang dibunuh itu tidak mati, tetapi hanya cidera, maka pelakunya juga akan cidera, seperti firman Allah:

"Hai orang-orang yang beriman, diwajibkan atas kamu qishash berkenaan dengan orang-orang yang dibunuh; orang merdeka dengan orang merdeka, hamba dengan hamba, dan wanita dengan wanita. Maka barangsiapa yang mendapat suatu pemaafan dari 
saudaranya, hendaklah (yang memaafkan) mengikuti dengan cara yang baik, dan hendaklah (yang diberi maaf) membayar (diat) kepada yang memberi maaf dengan cara yang baik (pula). Yang demikian itu adalah suatu keringanan dari Tuhan kamu dan suatu rahmat. Barangsiapa yang melampaui batas sesudah itu, maka baginya siksa yang sangat pedih (QS. al Baqarah: 178-179).

Memelihara akal Manusia adalah mahluk Allah. Ada dua hal yang membedakan manusia dengan mahluk lain. Pertama, Allah telah menjadikan manusia dalam bentuk yang paling baik dibandingkan dengan mahluk lain. Tetapi bentuk yang indah itu tidak ada gunanya kalau tidak ada hal yang kedua, yaitu akal. Seperti firman Allah dalam al Quran:

"Sungguh Kami telah menciptakan manusia dalam bentuk dan sifat yang sebaik-baiknya.

"Kemudian Kami kembalikan dia ke tempat yang serendah-rendahnya (neraka).Kecuali orang-orang yang beriman dan mengerjakan amal saleh; maka mereka akan mendapat pahala yang tidak ada putus-putusnya" (QS. at Tin: 4-6).

Memelihara keturunan untuk ini Islam mengatur pernikahan dan mengharamkan zina, menetapkan siapa-siapa yang tidak boleh dikawini, bagaimana cara-cara perkawinan itu dilakukan dan syarat apa yang harus dipenuhi, sehingga perkawinan itu dianggap sah dan percampuran antara dua manusia yang berlainan jenis itu tidak dianggap zina dan anak yang lahir dari hubungan itu dianggap sah dan menjadi keturunan sah dari ayahnya. Bahkan tidak hanya melarang itu saja, tetapi juga melarang hal yang dapat membawa kepada zina. Seperti firman Allah:

"Dan jika kamu takut tidak akan dapat berlaku adil terhadap (hak-hak) perempuan yang yatim (bilamana kamu mengawininya), maka kawinilah wanita-wanita (lain) yang kamu senangi: dua, tiga atau empat. Kemudian jika kamu takut tidak akan dapat berlaku adil, maka (kawinilah) seorang saja, atau budak-budak yang kamu miliki. Yang demikian itu adalah lebih dekat kepada tidak berbuat aniaya. Berikanlah maskawin (mahar) kepada wanita (yang kamu nikahi) sebagai pemberian dengan penuh kerelaan. Kemudian jika mereka menyerahkan kepada kamu sebagian dari maskawin itu dengan senang hati, maka makanlah (ambillah) pemberian itu (sebagai makanan) yang sedap lagi baik akibatnya" (QS. an Nisa: 3-4).

Memelihara harta benda dan kehormatan, meskipun pada hakikatnya semua benda itu kepunyaan Allah, namun Islam juga mengakui hak pribadi seseorang. Oleh karena manusia itu sangat tamak kepada harta benda, sehingga mau mengusahakannya dengan jalan apapun, maka Islam mengatur supaya jangan sampai terjadi bentrokan antara yang satu dengan yang lain. Untuk ini 
Islam mensyariatkan peraturan mengenai muamalat. Seperti firman Allah: "Hai orang-orang yang beriman, janganlah kamu memakan riba dengan berlipat ganda ${ }^{(1)}$ dan bertakwalah kamu kepada Allah supaya kamu mendapat keberuntungan" (QS. al Imran: 130)"

Untuk mengetahui konstribusi pengacara syariah dalam proses penegakan hukum Islam, tentu tidak sesederhana menjeaskan peberian bantuan hukum kepada fakir miskin yang harus diberikan secara cuma-cuma (prodeo). Meskipun pekerjaan bantuan hukum adalah pekerjaan yang mulia, tetapi pemerintah dan semua unsur masyarakat perlu mendorong eksistensi bantuan hukum kepada semua lapisan masyarakat.

Konstribusi advokat syariah dalam memberikan jasa bantuan hukum dan pembelaan pada kliennya tidak boleh dibedakan apakah yang dilanggar itu adalah hak kolektif atau hak individu. Namun demikian secara operasional dimungkinkan suatu organisasi bantuan hukum dapat menfokuskan pelayanannya pada suatu bidang tertentu karena kapasitas, kopetensi prioritas, dan karena adanya kebutuhan setempat. Konsep bantuan hukum dalam hukum Islam lebih mengedepankan terpeliharanya prinsip-prinsip dan asas-asas penegakan hukum Islam dan juga berorientasi pada kebenaran dan keadilan sesuai dengan tujuan syariah (maqashid al syariah). Selain itu juga setiap wilayah memiliki kebijakan lokal (Lokal Wisdom) dalam pelaksanaan Mediasi (Saifullah, 2014: 244).

Konstribusi advokat syariah yang berprofesi memberikan jasa atau bantuan hukum di Pengadilan Agama merupakan realitas hukum yang positif bagi pencari kebenaran dan penegakan keadilan. Konstribusi mereka digambarkan dalam beberapa hal sebagai berikut: (a) Mempercepat pelayanan administrasi, mulai dari proses pengajuan perkara, pertimbangan hukum, dan melakukan upaya hukum hingga bantuan kelancaran persidangan bagi kliennya di Pengadilan; (b) Membantu menghadirkan para pihak yang berperkara di pengadilan sesuai dengan jadwal persidangan dan membantu upaya perdamaian (islah) melalui media di dalam dan di luar pengadilan; (c) Memberikan pemahaman hukum yang baik dan benar kepada para pihak yang sedang berperkara dalam kaitannya dengan duduk perkara dan posisinya, terutama dalam menyampaikan permohonan atau gugatan atau menerima putusan; (d) Mendampingi para pihak yang berperkara di pengadilan berdasarkan prinsip keterwakilan (wakalah) dan/atau mewakili para pihak yang tidak dapat hadir dalam proses persidangan lanjutan, sehingga memperlancar proses 
persidangannya (Ramdani, 2012: 160). Sehingga para klien yang dibantunya merasa terayomi hak-hak hukum yang seadil-adilnya. (e) Dalam memberikan bantuan hukum, sebagai advokat profesional, tetap menjunjung tinggi sumpah advokat dan kode etik profesi dalam menjalankan sesuai dengan tugas dan fungsinya (Kusnadi, 2011: 242-243).

Berdasarkan paparan di atas, dapat dipahami bahwa konstribusi advokat syariah dalam menjalankan profesinya untuk memberi bantuan hukum dalam bentu apapun haruslah senantiasa berorientasi pada prinsip-prinsip dan asas-asas penegakan hukum Islam. Selain itu, banyak keuntungan yang akan didapatkan dengan adanya bantuan hukum syariah ini mulai dari proses administrasi hingga selesai. Demikian juga dari segi waktu dalam proses penyelesaian perkara tentu lebih cepat bila dibandingkan dengan perkara yang tidak menggunakan jasa advokat syariah. Hal ini disebkan advokat syariah adalah orang yang lebih paham akan hukum, mulai dari administrasi hingga selesai karena advokat syariah akan mengedepankan kepentingan kliennya.

\section{Simpulan}

Tugas advokat syariah secara umum sama seperti tugas advokat non syariah yakni membela kepentingan masyarakat (public defender) dan kliennya dalam menegakkan keadilan. Namun yang membedakannya dengan advokat non syariah adalah dalam memberikan pembelaan, pendampingan, dan menjadi kuasa untuk dan atas nama kliennya advokat syariah lebih berdasarkan pada prinsip tolong-menolong dan berpegang teguh pada sumber ajaran agama Islam. Dalam menjalankan profesi tersebut advokat mempunyai tanggung jawab kepada: tanggung jawab kepada negara, masyarakat, pengadilan, klien, tuhan, dan pihak lawan. Islam sangat menganjurkan adanya perdamaian atau islah dalam setiap perkara yang akan membutuhkan jasa bantuan hukum sebagai penengah dalam menyelesaikan perkaranya, dalam Islam sendiri terdapat tiga golongan pemberi bantuan hukum yaitu: hakam, mufti, dan Mushalailah-alailah. Namun dalam kaitannya dengan perdamaian dalam perkara perceraian maka dapat ditangani oleh seorang hakam. Sedangkan di dalam negara Indonesia hakam atau pemberi bantuan hukum dapat disebut advokat atau pengacara. Advokat yang berkompeten dalam menyelesaiakan perkara perceraian adalah advokat syariah yang mempunyai pedoman untuk selalu menjalankan profesinya sesuai dengan tujuan hukum syara (maqashid al syariah). 


\section{Daftar pustaka}

Abbas, Syahrizal. 2011. Mediasi dalam Hukum Syariah, Hukum Adat, dan Hukum Nasional. Jakarta: Prenada Media Group.

Abidin, Slamet dan Aminudin. 1999. Fiqih Munakahat 1. Bandung: CV. Pustaka Setia.

Adiyono, 2013. Mediasi Sebagai Upaya Hakim Menekan Perceraian di Pengadilan Agama. Jurnal al ihkam: Vol. 8 No. 1 2013: 126 - 140.

Handayani, Febri. 2015. Tinjauan Yuridis Terhadap Peranan Adwokat Dalam Mendampingi Klien Dalam Perkara Perceraian di Pengadilan Agama Kota Pekanbaru. Hukum Islam: Vol XV No. 1: Juni 2015 : 61 - 82.

Harahap, M. Yahya. 2012. Hukum Acara Perdata. Jakarta: Sinar Grafika.

Hariyanto, Erie 2014. Penyelesaian Sengketa Ekonomi Syariah di Indonesia. Iqthisadia: Vol. 1 No. 1 2014: $42-58$

Hariyanto, Erie 2017. Integrasi mediasi Sebagai Model Penyelesaian Sengketa Perbankan Syariah Masa Depan. Proseding ANCOMS 2017: 34-45

Hariyanto, Erie. 2016. Tinjauan Yuridis Integrasi Mediasi dalam Sistem Peradilan. Pamekasan: STAIN Press.

Ikatan Hakim Indonesia. 2016. Majalah Hukum Varia Peradilan. Jakarta: IKAHI.

Kusnadi, Didi. 2011. Bantuan Hukum dalam Hukum Islam. Tt: Kementrian Agama RI.

Kussunaryatun. 2010. Analisis Faktor Penghambat Mediasi dalam Sengketa Perdata di Pengadilan Negeri Surakarta, Yustisia, Edisi 81 September - Desember.

Mannan, Abdul. 2006. Penerapan Hukum Acara Perdata di Lingkungan Peradilan Agama. Jakarta: Kencana.

Mustaming. 2014. Tinjauan Yuridis Penyelesaian Sengketa di Pengadilan Agama Melalui Proses Mediasi. Jurnal al Ahkam: Vol. IV, No. 2 Agustus.

Saifullah, 2014. Integrasi Mediasi Kasus Perceraian dalam Beracara di Pengadilan Agama. Jurnal al Ahkam: Volume 24, Nomor 2, Oktober 2014: 243-262.

Syah, Ismail. 1999. Filsafat hukum Islam. Jakarta: PT Bumi Aksara. 
Pramudya, Kelik dan Ananto Widiatmoko. 2010. Pedoman Etika Profesi Aparat Hukum. Yogyakarka: Pustaka Yustisia.

Pramudya, Kelik.2011.Panduan Praktis Menjadi Advokat. Yogyakarta: Pustaka Yustisia.

Ramdani, Wahyu Sururie. 2012. Implementasi Mediasi dalam Sistem Peradilan Agama. Vol 12 No. 2 Desember : 145-164.

Soejono dan Abdurahman. 2003. Metodologi Penelitian Hukum. Jakarta: Rineka Cipta.

Supriadi. 2016. Etika dan Tanggung Jawab Profesi Hukum di Indonesia. Jakarta: Sinar Grafika.

Suryabrata, Sumadi. 2005. Metode Penelitian. Jakarta: PT Raja Grafindo Persada.

Wahyudi, Yudian. 2007. Ushul Fikih Versus Hermeneutika. Yogyakarta: Nawesea.

Witanto, D. Y. 2011. Hukum Acara Mediasi. Bandung: Alfabeta. 